\title{
K/Ar geochronology of igneous amphibole phenocrysts in Miocene to Pliocene volcaniclastics, Styrian Basin, Austria
}

\author{
Hans-Peter BOJAR ${ }^{1, *}$, Ana-Voica BOJAR ${ }^{1,2}$, Stanisław HAŁAS ${ }^{3}$ \\ and Artur WÓJTOWICZ \\ 1 Department of Earth Sciences - Mineralogy, Studienzentrum Naturkunde, Universalmuseum Joanneum, Weinzöttlstraße \\ 16, A-8045 Graz, Austria \\ 2 Department of Geography and Geology, Paris-Lodron University Salzburg, Hellbrunnerstraße 34, A-5020, Salzburg, Austria \\ 3 Mass Spectrometry Laboratory, Institute of Physics, Maria Curie-Skłodowska University, 20-031 Lublin, Poland
}

Bojar H.-P., Bojar A.-V., Hałas S. and Wójtowicz A. (2013) K/Ar geochronology of igneous amphibole phenocrysts in Miocene to Pliocene volcaniclastics, Styrian Basin, Austria. Geological Quarterly, 57 (3): 405-416, doi: 10.7306/gq.1102

\begin{abstract}
We present fifteen new K/Ar ages on amphibole phenocrysts of Neogene volcaniclastic rocks from the Styrian Basin, Austria. The westernmost sub-basin of the Pannonian Basin is the Styrian Basin, which hosts a large number of phreatomagmatic tuff occurrences beside Middle Miocene shield volcanoes and Pliocene effusive alkaline volcanic rocks. The investigated tuffs contain the well-known mantle xenoliths and frequent amphibole and pyroxene phenocrysts. The new K/Ar ages indicate that the Late Miocene phreatomagmatic volcanism started in Pontian (7.51 Ma) and ended in Romanian (2.73 Ma) times. The complete interval of the youngest volcanism in the Styrian Basin covers $5.8 \mathrm{Ma}$, similar to the volcanism of the western part of the Pannonian Basin and the Nógrád/Novohrad area (West Carpathians). The dated volcanic occurrences display NNW-SSE oriented arrays which are approximately parallel to the Auersbach basinal high zone. The new data indicate that the Late Miocene to Pliocene volcanism of the Styrian Basin is synchronous with the onset of a regional compressional event and eastward tilting of the Styrian Basin fill.
\end{abstract}

Key words: geochronology, igneous amphibole, volcanic tuffs, Styrian Basin.

\section{INTRODUCTION}

The westernmost sub-basin of the Pannonian Basin is the Styrian Basin, which is situated at the southeastern margin of the Eastern Alps. Several basement highs divide the Styrian Basin into two sub-basins: the Middle Styrian basement high separates the shallower Western Styrian Basin (with $\sim 800 \mathrm{~m}$ thick Neogene sediments) from the Eastern Styrian Basin (with a 3000 $\mathrm{m}$ thick infill). The South Burgenland basement high, separates the West Pannonian Basin from the Styrian Basin (Kollmann, 1964; Flügel and Neubauer, 1984). The N-S-trending Auersbach basement high divides the Eastern Styrian Basin into two sub-basins (Figs. 1 and 2).

The Eastern Styrian Basin hosts distinct volcanic depocentres represented by Miocene (Karpatian to Badenian) shield volcanoes and volcanic tuff intercalations in sediments. The second phase of basaltic volcanism has a Late Miocene to Pliocene age. The Western Styrian Basin hosts only one Middle

\footnotetext{
* Corresponding author, e-mail:

hans-peter.bojar@museum-joanneum.at
}

Received: December 27, 2012; accepted: March 16, 2013; first published online: May 23, 2013
Miocene volcano. Most of the Middle Miocene volcanics are covered by sediments and are known only from boreholes and geophysical studies (Kollmann, 1964; Kröll et al., 1988). Approximate 30-40 Pliocene eruption centres are known (Kollmann, 1964), several of them in a very close proximity to others, therefore merged to one occurrence (Fig. 3).

Numerous geochronological studies were done for effusive rocks of Miocene and Pliocene age as well as for Miocene tuffs (e.g., Steininger and Bagdasarjan, 1977; Balogh et al., 1994; Handler et al., 2006). In Table 1, all known geochronological data of the volcanic rocks of the Styrian Basin are given. A systematic geochronological study on the phreatomagmatic tuff occurrences lacks so far. The purpose of this study is to date the tuffs within the Styrian Basin and to correlate them with the occurrences from the adjoining areas.

\section{GEOLOGICAL/TECTONIC SETTING OF THE ALPINE-CARPATHIAN-PANNONIAN BLOCK}

The Alps delimitate the Pannonian Basin to the west (mainly the Austroalpine nappe system, except the Rechnitz Window, which is part of the Penninic units). North- and eastward, the Pannonian Basin is bordered by the Carpathians, southward by the Dinaride orogenic belt (Fig. 1). 


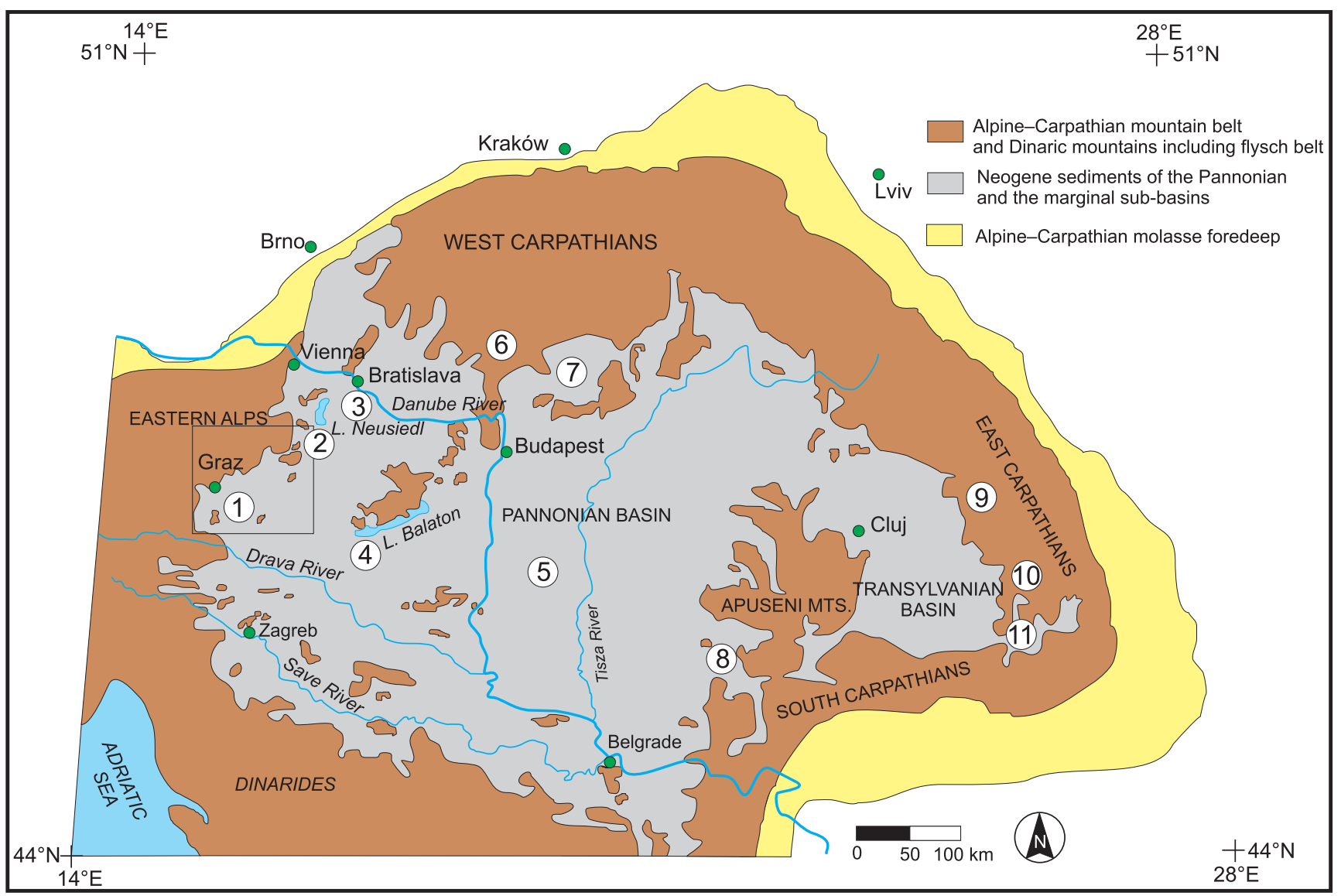

Fig. 1. Simplified geological map of the Alpine-Carpathian-Pannonian region (modified from Horváth, 1995) showing the Miocene to Quaternary mafic alkaline volcanic areas: 1 - Styrian Basin, 2 - Burgenland, 3 - Little Hungarian Plain/Danube Basin, 4 Transdanubian Central Range/Balaton, 5 - Bar, 6 - Central Slovak Volcanic Field, 7 - Nógrád /Novohrad, 8 - Banat, 9 - Calimani Mts., 10 - Harghita Mts., 11 - Perşani Mts.; square shows the position of Figure 2

The Late Oligocene and Miocene north-eastward transpressive movement of the Adriatic plate and the collision with Europe led to shortening and crustal overthickening. This event generated sinistral fault systems to the north and dextral fault systems to the south (Periadriatic lineament and associated strike-slip zones) of the Alps. Lateral motion of the crust includes tectonic escape of wedges and extensional collapse from the morphological high of the Tauern window area towards the basin (Ratschbacher et al., 1991). Related to this event, the Alpine-Carpathian realm and Pannonian Basin were formed by collision-related Miocene extension. The Pannonian Basin developed on the top of the resulting extruding wedge (Royden et al., 1983; Neubauer, 1988; Genser and Neubauer, 1989; Ratschbacher et al., 1989; Neubauer and Genser, 1990). The eastward extension was enhanced also by a retreat of the subduction boundary in the Carpathians. The westward-dipping subduction zone and rollback consumed the thinned European oceanic and continental crust (Royden, 1993) and caused further Early to Middle Miocene extension in the Pannonian Basin (Tari et al., 1992; Horváth, 1993; Royden, 1993; Peresson and Decker, 1996).

An overview of the tectonic setting and regional geologic evolution of the Pannonian Basin is given by Huismans et al. (2002) using data from Bergerat (1989), Csontos et al. (1991), Ratschbacher et al. (1993), Horváth (1995), Bergerat (1995), Csontos (1995), Fodor (1995), Hippolyte and Sandulescu (1996), Sachsenhofer (1996), Sachsenhofer et al. (1997), Huismans et al. (1997), Mațenco (1997), Peresson and
Decker (1997a, b), Sanders (1998), Fodor et al. (2000) and Huismans and Bertotti (2002). According to Huismans et al. (2002), the Early to Late Miocene extension led to a significant thinning of the lithosphere (down to 60 to $80 \mathrm{~km}$ with a crustal thickness of $\sim 22.5$ to $30 \mathrm{~km}$ ) with high gradients of lithosphere thickness in the eastern and western basin border regions. The thin lithosphere of the Pannonian Basin is coupled with a high heat flow (Sclater et al., 1980; Horváth et al., 2006) and updoming of the asthenosphere. The crustal thickness of the surrounding Alpine and Carpathian mountain chain is $\sim 100$ to 200 km (Horváth, 1993).

Oligocene to Early Miocene pre-rift compression: the last major tectonic event before extension in the Pannonian Basin is an N-S to NW-SE compression in the eastern Alps.

Middle to Late Miocene first rift phase: the first extensional phase took place between 17.5 to $14 \mathrm{Ma}$, with local development of deep basins associated with crustal thinning. The Karpatian stage was characterized by opening of pull-apart basins at the rim of the Pannonian Basin (Vienna and Styrian basins in the west, East Slovak Basin in the north-east, Drava and Sava troughs in the south-west, and Bekes and Mako troughs in the east). Ongoing $\mathrm{E}-\mathrm{W}$ extension thinned the central parts of the Pannonian region and affected the whole area between the Eastern Alps and the Eastern Carpathians. During latest Karpatian time, tectonic movements caused uplift of the Styrian Basin hinterland as well as of the basement highs and erosion along the basin margins. 


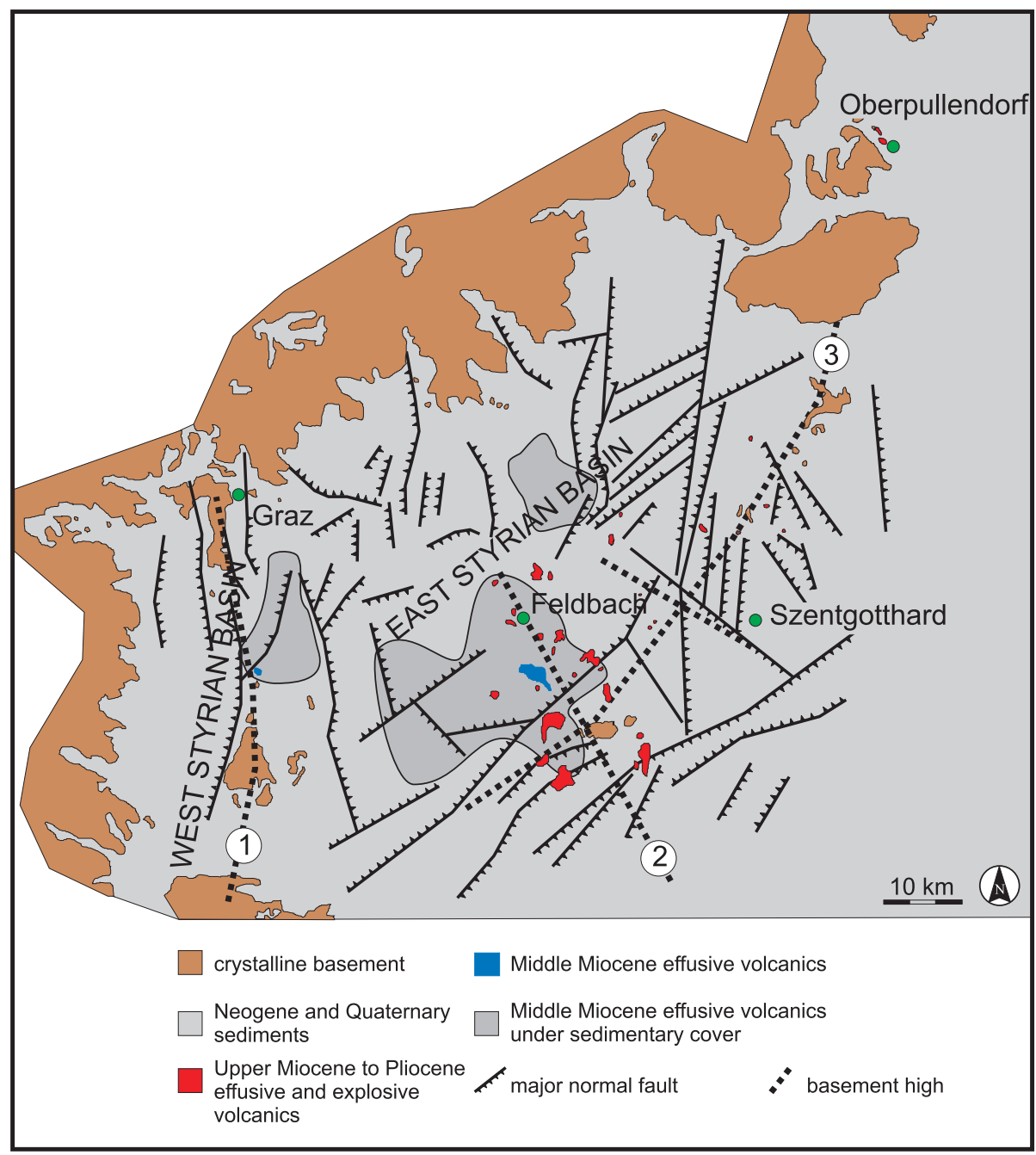

Fig. 2. Simplified geological and tectonic map of the Styrian Basin (based on Kröll, 1988) with basement highs and volcanics, in part under sedimentary cover

1 - Middle Styrian basement high; 2 - Auersbach basement high; 3 - South Burgenland basement high

Late Sarmatian inversion: a compressional event affected the Pannonian Basin during the Late Sarmatian. Missing Sarmatian sediments in many parts of the Pannonian Basin are related to uplift and erosion. During the Early Pannonian, sedimentation and subsidence were re-established.

Late Sarmation-Early Pannonian second rift phase: extensional structures in the western and central part of the Pannonian Basin evidence for a second rift phase, higher sedimentation rates being documented for this period $(\sim 11.5$ to $8 \mathrm{Ma})$. Synchronously, for the eastern and western marginal areas of the Pannonian Basin a strong compressional pulse was documented.

Pannonian inversion and compression: from the Late Miocene onwards, the Pannonian Basin has been progressively closed. The stress field of the mountain areas surrounding the Pannonian Basin was of strike-slip type, with the main direction of the compression ca. normal in respect to the strike of the orogen. In the Styrian Basin, the subsidence ceased during the Early Pannonian, thin Pannonian sediments being restricted to the Eastern Styrian Basin. The peripheral portions of the Styrian Basin are down-bended, with depocentres moving eastwards during tilting, which is contemporaneous with major subsidence in the Little Hungarian Plane. The second phase of basaltic volcanism took place in this period (Balogh et al., 1994; Seghedi et al., 2004).

Due to high resistance to weathering compared to the surrounding sediments, the volcaniclastic deposits form today prominent highs in the landscape, as for example Riegersburg, Güssing, Neuhaus and Kapfenstein. The tuffs of the Styrian Basin were used since centuries as building stones; for this reason a high number of small-scale quarries can be found. The mining of these rock-types dates back as long as medieval times, the fortresses and castles of Riegersburg, Güssing, Neuhaus and Kapfenstein being well known. Most of these quarries which were closed in the second half of the 20th century are today overgrown and hardly accessible.

Three volcanic events can be distinguished in the Styrian Basin: (1) Lower/Middle Miocene volcaniclastics and high-K effusive volcanic rocks, (2) alkaline effusive rocks of Early Pannonian age and (3) Pliocene alkaline effusive rocks and Upper Miocene to Pliocene volcaniclastic tuffs. Whole rock $\mathrm{K} / \mathrm{Ar}$ data of the Pliocene alkaline effusive rocks (Balogh et al., 1994) gave an age range from 3.8 to $1.7 \mathrm{Ma}$ (Table 1) for the Styrian Basin. 


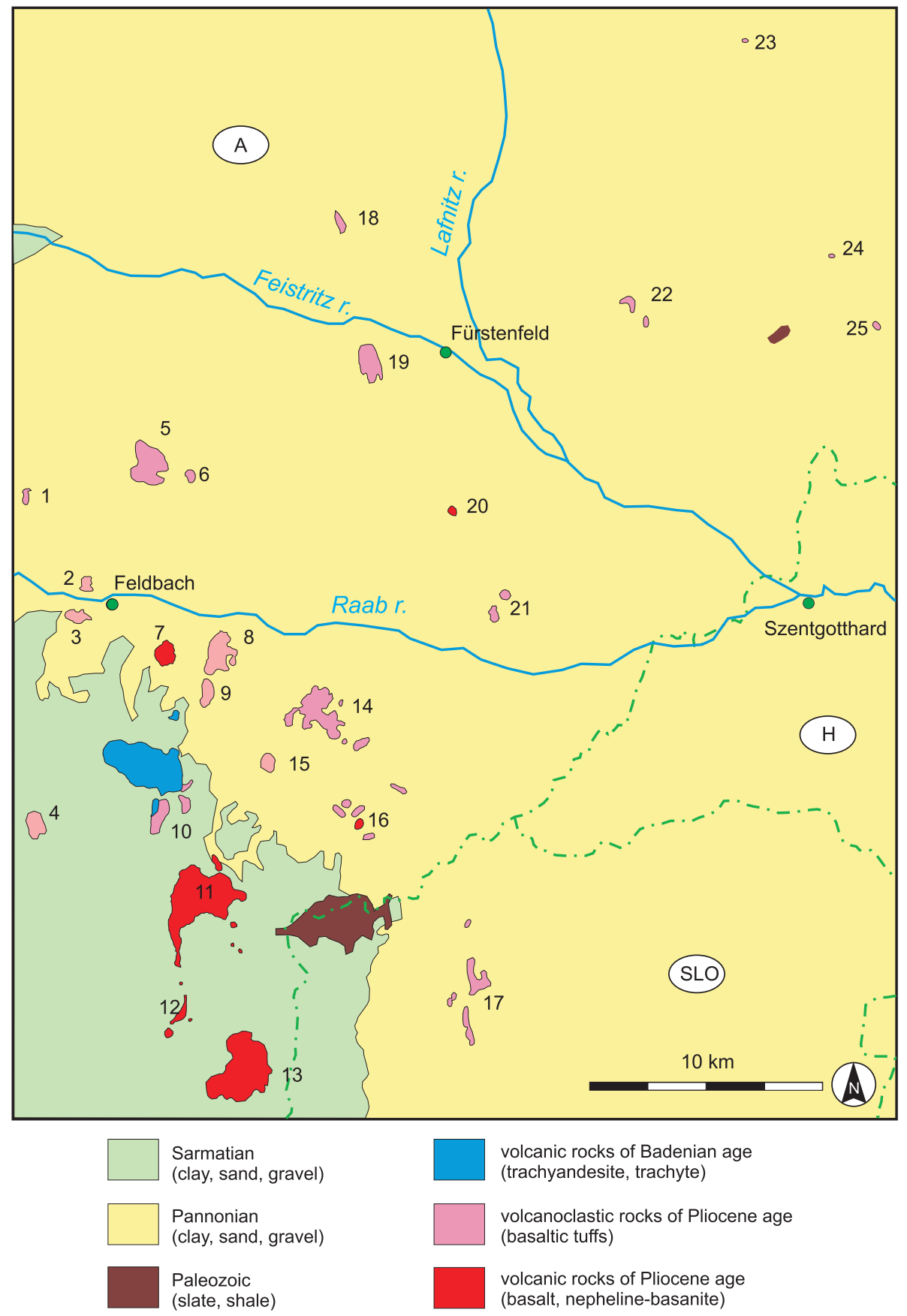

Fig. 3. Simplified geological map of the Eastern Styrian Basin and adjoining areas

1 - Edelsbach SV6; 2 - Auersbach SV7A; 3 - Unterweißenbach SV7B; 4 - Gnas SV14; 5 Altenmarkt; 6 - Riegersburg SV4B; 7 - Mühldorf; 8 - Pertlstein 25629; 9 - Forstkogel SV9C; 10 Bad Gleichenberg SV12F; 11 - Wilhelmsdorf; 12 - Tieschen; 13 - Klöch; 14 - Burgfeld SV10A-a, SV10B-a; 15 - Kapfenstein SV11B-a; 16 - Neuhaus; 17 - Grad; 18 - Jobst; 19 - Stadtbergen SV3A; 20 - Stein bei Fürstenfeld; 21 - Jennersdorf; 22 - Limbach SV20-a; 23 - Neuberg; 24 Tobaj SV22-a; 25 - Güssing SV21

\section{XENOLITHS}

A variety of different types of xenoliths can be found in the basaltic tuff occurrences of the Styrian Basin and its adjacent area. Beside rocks and minerals of sedimentary and metamorphic origin, a minimum of four xenoliths types can be distinguished: (1) granites and gneisses, (2) andesites (related to the older Lower to Middle Miocene volcanism), (3) ultramafic xeno- liths (peridodite, Iherzolite, websterite, harzburgite, hornblendites), (4) hornblende, augite and olivine phenocrysts (Heritsch, 1908; Schadler, 1913).

Mostly, amphibole phenocrysts can be found as loose components of the volcanic tuffs. Especially smaller amphiboles show crystallographic terminations with the dominant forms $\{110\}$ and $\{010\}$. Larger crystals are sometimes embedded in an alkali basaltic rock (Fig. 4). 
Table 1

Compilation of geochronological data of volcanics from the Styrian Basin and adjacent areas

\begin{tabular}{|c|c|c|c|c|c|c|}
\hline No. & Locality & Age [Ma] & Material & Method & Rock type & Reference \\
\hline 1 & Grad & 3.37 & $w r$ & $\mathrm{~K} / \mathrm{Ar}$ & VS & 1 \\
\hline 2 & Güssing & 6.3 & $w r$ & $\mathrm{~K} / \mathrm{Ar}$ & VS & 1 \\
\hline 3 & Kapfenstein & 4.68 & $w r$ & $\mathrm{~K} / \mathrm{Ar}$ & VS & 1 \\
\hline 4 & Klöch & 2.56 & $w r$ & $\mathrm{~K} / \mathrm{Ar}$ & $\mathrm{EF}$ & 2 \\
\hline 5 & Mühldorf & 2.64 & $w r$ & $\mathrm{~K} / \mathrm{Ar}$ & EF & 2 \\
\hline 6 & Mühldorf & 3.05 & $w r$ & $\mathrm{~K} / \mathrm{Ar}$ & EF & 2 \\
\hline 7 & Neuhaus & 3.11 & $w r$ & $\mathrm{~K} / \mathrm{Ar}$ & EF & 2 \\
\hline 8 & Neuhaus & 3.11 & $w r$ & $\mathrm{~K} / \mathrm{Ar}$ & EF & 1 \\
\hline 9 & Neuhaus & 3.76 & $w r$ & $\mathrm{~K} / \mathrm{Ar}$ & EF & 2 \\
\hline 10 & Tieschen & 2.17 & $w r$ & $\mathrm{~K} / \mathrm{Ar}$ & $\mathrm{EF}$ & 1 \\
\hline 11 & Unterweissenbach & 2.27 & $w r$ & $\mathrm{~K} / \mathrm{Ar}$ & VS & 2 \\
\hline 12 & Wilhelmsdorf & 1.71 & $w r$ & $\mathrm{~K} / \mathrm{Ar}$ & $\mathrm{EF}$ & 2 \\
\hline 13 & Oberpullendorf & 11.1 & $w r$ & $\mathrm{~K} / \mathrm{Ar}$ & EF & 2 \\
\hline 14 & Pauliberg & 10.5 & $w r$ & $\mathrm{~K} / \mathrm{Ar}$ & EF & 2 \\
\hline 15 & Pauliberg & 11.0 & $w r$ & $\mathrm{~K} / \mathrm{Ar}$ & EF & 2 \\
\hline 16 & Pauliberg & 11.7 & $w r$ & $\mathrm{~K} / \mathrm{Ar}$ & EF & 2 \\
\hline 17 & Pauliberg & 12.3 & $w r$ & $\mathrm{~K} / \mathrm{Ar}$ & EF & 2 \\
\hline 18 & Bad Gleichenberg & 13.2 & st & $\mathrm{K} / \mathrm{Ar}$ & EF & 2 \\
\hline 19 & Bad Gleichenberg & 14.6 & $w r$ & $\mathrm{~K} / \mathrm{Ar}$ & EF & 3 \\
\hline 20 & Bad Gleichenberg & 14.9 & biotite & $\mathrm{K} / \mathrm{Ar}$ & EF & 4 \\
\hline 21 & Bad Gleichenberg & 15.4 & alunite & $\mathrm{K} / \mathrm{Ar}$ & EF & 4 \\
\hline 22 & Bad Gleichenberg & 15.4 & $w r$ & $\mathrm{~K} / \mathrm{Ar}$ & EF & 5 \\
\hline 23 & Bad Gleichenberg & 15.4 & $w r$ & $\mathrm{~K} / \mathrm{Ar}$ & EF & 5 \\
\hline 24 & Bad Gleichenberg & 15.8 & $w r$ & $\mathrm{~K} / \mathrm{Ar}$ & EF & 5 \\
\hline 25 & Bad Gleichenberg & 16.8 & $w r$ & $\mathrm{~K} / \mathrm{Ar}$ & EF & 5 \\
\hline 26 & Bad Gleichenberg & 22.97 & wr & $\mathrm{Rb} / \mathrm{Sr}$ & EF & 6 \\
\hline 27 & Hörmsdorf & 15.08 & biotite & $\mathrm{Ar} / \mathrm{Ar}$ & VCL & 7 \\
\hline 28 & Hörmsdorf & 15.22 & biotite & $\mathrm{Ar} / \mathrm{Ar}$ & VCL & 7 \\
\hline 29 & Oberdorf & 18.7 & zircon & $\mathrm{FT}$ & VCL & 8 \\
\hline 30 & Pöls & 14.9 & biotite & $\mathrm{K} / \mathrm{Ar}$ & VCL & 2 \\
\hline 31 & Pöls & 15.3 & biotite & $\mathrm{K} / \mathrm{Ar}$ & VCL & 2 \\
\hline 32 & Pöls & 15.75 & biotite & $\mathrm{Ar} / \mathrm{Ar}$ & VCL & 7 \\
\hline 33 & Pöls & 16.6 & biotite & $\mathrm{Ar} / \mathrm{Ar}$ & VCL & 2 \\
\hline 34 & Retznei & 14.21 & biotite & $\mathrm{Ar} / \mathrm{Ar}$ & VCL & 7 \\
\hline 35 & Retznei & 14.39 & sanidine & $\mathrm{Ar} / \mathrm{Ar}$ & VCL & 7 \\
\hline 36 & Tregistsattel Oberdorf & 16.0 & zircon & $\mathrm{FT}$ & VCL & 8 \\
\hline 37 & Tregistsattel Oberdorf & 17.5 & biotite & $\mathrm{K} / \mathrm{Ar}$ & VCL & 2 \\
\hline 38 & Weitendorf & 14.0 & wr & $\mathrm{K} / \mathrm{Ar}$ & EF & 2 \\
\hline 39 & Weitendorf & 15.2 & $w r$ & $\mathrm{~K} / \mathrm{Ar}$ & EF & 3 \\
\hline 40 & Weitendorf & 15.8 & $w r$ & $\mathrm{~K} / \mathrm{Ar}$ & $\mathrm{EF}$ & 5 \\
\hline 41 & Weitendorf & 16.1 & $w r$ & $\mathrm{~K} / \mathrm{Ar}$ & $\mathrm{EF}$ & 5 \\
\hline 42 & Weitendorf & 16.1 & $w r$ & $\mathrm{~K} / \mathrm{Ar}$ & EF & 5 \\
\hline 43 & Weitendorf & 16.3 & $w r$ & $\mathrm{~K} / \mathrm{Ar}$ & $E F$ & 5 \\
\hline 44 & Weitendorf & 16.6 & $w r$ & $\mathrm{~K} / \mathrm{Ar}$ & EF & 5 \\
\hline 45 & Weitendorf & 17.3 & $w r$ & $\mathrm{~K} / \mathrm{Ar}$ & EF & 5 \\
\hline 46 & Weitendorf & 17.5 & $w r$ & $\mathrm{~K} / \mathrm{Ar}$ & $\mathrm{EF}$ & 5 \\
\hline
\end{tabular}

wr - whole rock, VS - volcano-sedimentary rock, EF - effusive rock, VCL - volcaniclastic layer/patches in Miocene sedimentary rock; references: 1 - Seghedi et al. (2004), 2 - Balogh et al. (1994), 3 - Lippolt et al. (1975), 4 - Bojar et al. (2008), 5 - Steininger and Bagdasarjan (1977), 6 - Kolmer (1980), 7 - Handler et al. (2006), 8 - Ebner et al. (2002) 

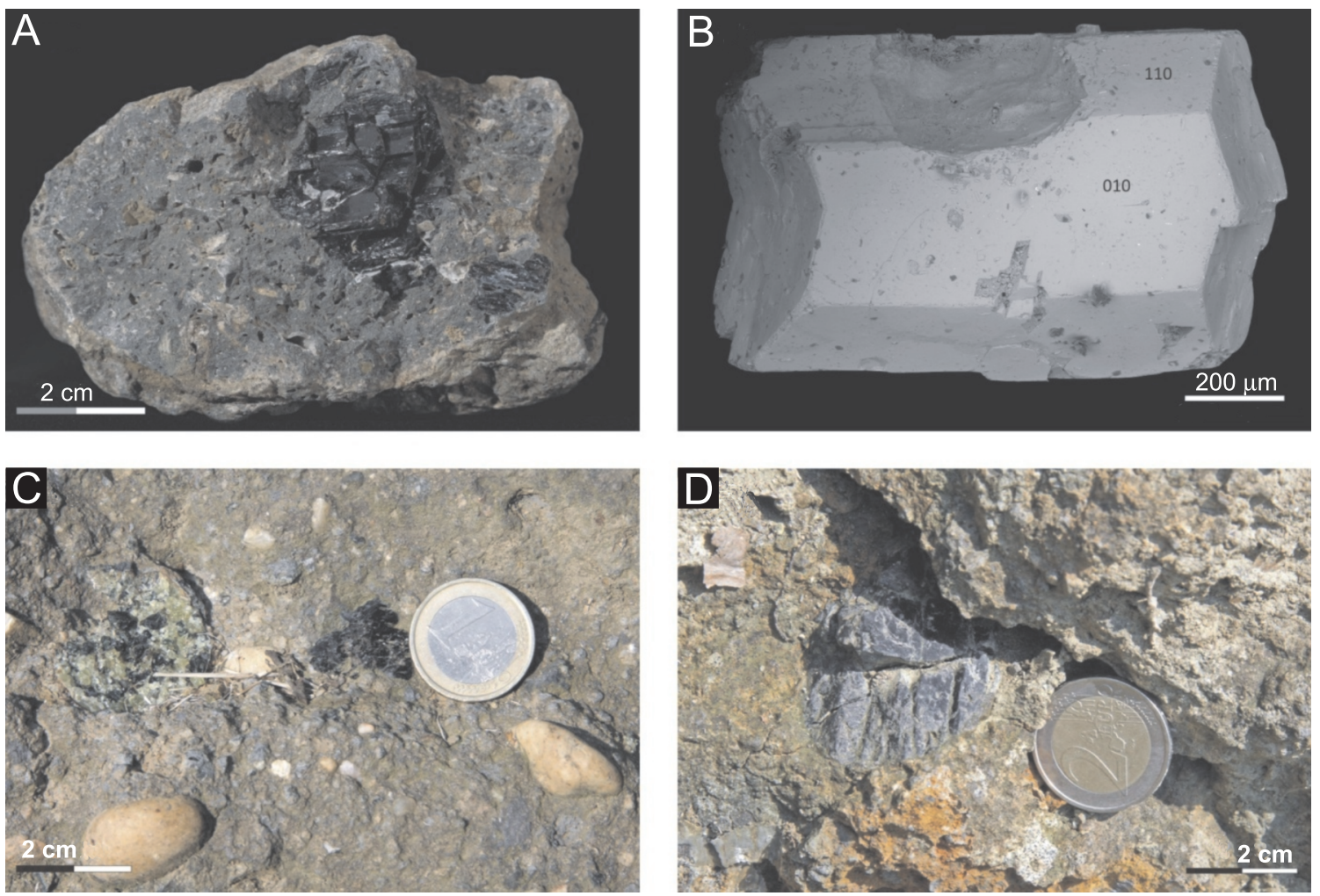

Fig. 4A - amphibole phenocryst in alkali basaltic rock, Tobaj; B - amphibole phenocryst with crystallographic terminations, Edelsbach, backscattered electron image; $\mathrm{C}$ - amphibole phenocryst and an ultramafic xenolith in volcanic tuff rich in country rocks, Kapfenstein, diameter of coin $23 \mathrm{~mm}$; D - amphibole phenocryst in volcanic tuff, Limbach, diameter of coin $26 \mathrm{~mm}$

\section{SAMPLE PREPARATION AND ANALYTICAL DATA}

Sample preparation: amphibole phenocrysts were collected from all fifteen tuff occurrences of the Styrian Basin and adjoining areas (Fig. 3). Only unaltered crystals with no secondary mineral formation like calcite or zeolite on the surface or in cracks were used for K/Ar dating. Separation from host rock was done by hand-picking. The amphibole crystals were ultrasonically cleaned in acetone and rinsed with deionised water. The crystal size mostly exceeds one centimetre. Amphibole of a hornblendite-xenolith was used only in one case (Stadtbergen).

$\mathrm{K} / \mathrm{Ar}$ data: the $\mathrm{K}$ contents were determined by thermal isotope mass spectrometry (TIMS) using the isotope dilution technique, as described by Hałas (2001). Radiogenic argon concentration $\left({ }^{40} \mathrm{Ar}^{*}\right)$ was determined on the instrumental setup of the Mass Spectrometry Laboratory described in detail by Durakiewicz (1995). The analytical results are presented in Table 1 . The overall standard uncertainty (given in $1 \sigma$ ) resulting from uncertainties of $\mathrm{K}$ and ${ }^{40} \mathrm{Ar}^{*}$ determinations was calculated by the error propagation formula derived by Cox and Dalrymple (1967).

\section{RESULTS}

Almost all the volcanic tuffs of the Styrian Basin and adjacent areas host mantle xenoliths as well as amphibole and pyroxene phenocrysts. The new K/Ar geochronological data of
15 magmatic amphiboles from the tuffs are given in Table 2. For the explosive volcanism, the ages range from 2.73 to $7.51 \mathrm{Ma}$. The sample locations and some of the dated phenocrysts are shown in Figures 3 and 4, respectively.

Most of the Upper Miocene to Pliocene volcanic rocks of the Styrian Basin are situated on two basinal high zones: the SW-NE trending South Burgenland Zone and the NNW-SSE trending Auersbach Zone. These zones are bordered by steep normal faults, which have been already active since Karpatian times (Friebe, 1991; Sachsenhofer, 1996).

From west to east, roughly four NNW-SSE arrays of volcanic occurrences can be distinguished. The westernmost array is situated on the western slope of the Auersbach basinal high zone and hosts most of the effusive sodium alkaline volcanics as Klöch, Tieschen, Wilhelmsdorf and Mühldorf and the tuffs of Bad Gleichenberg, Gnas, Unterweißenbach, Gniebing and Edelsbach. The high-K to shoshonitic calc-alkaline volcanics from Bad Gleichenberg of Middle Badenian age, are also included in this zone. The second array, represented by Grad, Neuhaus, Kapfenstein, Burgfeld, Forstkogel, Pertlstein, Riegersburg and Altenmarkt, is situated on the eastern slope of the Auersbach basinal high. Beside numerous phreatomagmatic volcanics, only one effusive sodium alkaline basalt (Neuhaus) is hosted in this zone. These two zones situated westward and eastward of the Auersbach high, host $\sim 2 / 3$ of the Late Miocene to Pliocene volcanics of the Styrian Basin. The third array, including Jennersdorf, Stein, Stadtbergen and Jobst, hosts also the basalt from Stein. The tuffs from Jennersdorf and Jobst lack xenoliths and igneous phenocrysts; ultramafic xenoliths and phenocrysts suitable for dating were found only at Stadtbergen. The fourth array consists of Güssing, Tobaj and Neuberg. The Limbach tuff is located between zones three and four. 
Table 2

K/Ar analytical data on amphibole phenocrysts of Upper Miocene to Pliocene volcanic tuffs from the Styrian Basin and adjacent areas

\begin{tabular}{|l|c|c|c|c|c|c|}
\hline No. & Sample & Locality & $\% \mathrm{~K}$ & $\begin{array}{c}\mathrm{Ar} \\
{[\mathrm{pmol} / \mathrm{g}]}\end{array}$ & $\%$ Ar* & Age [Ma] \\
\hline 1 & SV3-a & Stadtbergen & 1.057 & 11.89 & 30.7 & $6.48 \pm 0.12$ \\
\hline 2 & SV6-a & Edelsbach & 1.58 & 10.20 & 26.2 & $3.52 \pm 0.09$ \\
\hline 3 & SV7A-a & Auersbach & 1.462 & 7.29 & 19.5 & $2.87 \pm 0.08$ \\
\hline 4 & SV7B-a & Unterweißenbach & 1.590 & 7.52 & 20.8 & $2.73 \pm 0.08$ \\
\hline 5 & SV10A-a & Kuruzzenkogel & 1.64 & 14.70 & 37.0 & $5.15 \pm 0.08$ \\
\hline 6 & SV10B-a & Beistein & 2.030 & 20.54 & 35.3 & $5.82 \pm 0.06$ \\
\hline 7 & SV11B-a & Kapfenstein & 1.772 & 14.96 & 38.6 & $4.86 \pm 0.06$ \\
\hline 8 & SV20-a & Limbach & 1.62 & 16.11 & 57.36 & $5.72 \pm 0.06$ \\
\hline 9 & SV22-a & Tobaj & 1.63 & 14.11 & 44.29 & $4.98 \pm 0.08$ \\
\hline 10 & 25629 & Pertlstein & 1.73 & 9.97 & 19.86 & $3.32 \pm 0.12$ \\
\hline 11 & SV9C & Forstkogel & 20.8 & 35.1 & 26.6 & $7.51 \pm 0.09$ \\
\hline 12 & SV4B & Riegersburg & 1.56 & 10.1 & 38.8 & $3.71 \pm 0.06$ \\
\hline 13 & SV12F & Bad Gleichenberg & 1.76 & 16.1 & 25.0 & $5.26 \pm 0.07$ \\
\hline 14 & SV14A & Gnas & 1.68 & 8.4 & 39.2 & $2.88 \pm 0.05$ \\
\hline 15 & SV21 & Güssing & 1.65 & 14.3 & 43.8 & $5.03 \pm 0.08$ \\
\hline
\end{tabular}

bó et al., 1992), probably the intra-Carpathian area and the Carpathian volcanic arc itself (Pécskay et al., 2006).

Middle Miocene to recent medium to high-K calc-alkaline volcanism. Parallel to the inner margins of the Alpine-Carpathian Arc, high-K calc-alkaline volcanic rocks and subordinate shoshonites are found. Calc-alkaline volcanism in northern Hungary is intermediate between medium to high-K calc-alkaline (Downes et al., 1995a), whereas the volcanism in the Styrian Basin is high-K to shoshonitic (Slapansky et al., 1999). The calc-alkaline volcanism is represented by basaltic to rhyolitic lava flows, dikes and dome-flows, and is characterized by decreasing ages from $\mathrm{W}$ to $\mathrm{E}$. The volcanism started in the Styrian Basin at 16.8 to 15.5 Ma (Pécskay et al., 1995b, 2006; Handler et al., 2006) and in the Danube Basin at 16.5 to $15 \mathrm{Ma}$ (Kantor et al., 1987). The age of calc-alkaline volcanism decreases to the east and south-east with the youngest ages found in the East Carpathians, i.e., Calimani-Perşani-Harghita Mountains (10.6 to 0.15 Ma) (Peltz et al., 1987; Szakács et al., 1993; Pécskay et al., 1995b, 2006; Moriya et al., 1996).

\section{DISCUSSION}

\section{REGIONAL NEOGENE VOLCANISM}

The Neogene evolution of the Alpine-Carpathian-Pannonian (ALCAPA) area was accompanied by frequent volcanic activity (Szabó et al., 1992; Balogh et al., 1994; Dobosi et al., 1995; Downes and Vaselli et al., 1995; Downes et al., 1995a; Ebner and Sachsenhofer, 1995; Embey-Isztin and Dobosi, 1995; Harangi et al., 1995a, b; Kaličiak and Žec, 1995; Konečný et al., 1995b; Lyashkevich, 1995; Pécskay et al., 1995a, b, 2006; Seghedi et al., 1995, 2004, 2011; Vaselli, 1995; Moriya et al., 1996; Sachsenhofer, 1996; Slapansky et al., 1999; Németh et al., 2001; Ebner et al., 2002; Handler et al., 2006; Bojar et al., 2008; Kralj, 2011).

In the Pannonian Basin and in the West Carpathians, the volcanism started during Eggenburgian times ( 19.5 Ma). The youngest ages of 35 to $150 \mathrm{ka}$ (Moriya et al., 1996) are found in the East Carpathians (Perşani and Harghita Mountains). According to the data, the volcanic activity in the Alpine-Carpathian-Pannonian region covers over $19 \mathrm{Ma}$ and can be classified in a calc-alkaline and alkaline type:

Early Miocene to Middle Miocene calc-alkaline intermediate to acidic volcanic tuffs. Lower to Middle Miocene acidic tuffs are widespread within the Pannonian Basin as well as within its marginal and intra-mountain basins (Ebner, 1981; Ebner and Gräf, 1982; Pécskay et al., 1995b and references therein, Handler et al., 2006). Pécskay et al. (1995b) discern three tuff-events in the Pannonian Basin: Lower (18-19.5 Ma), Middle (15-16.4 Ma) and Upper Rhyolite Tuffs (11-13.5 Ma). The Lower Rhyolite Tuff horizon is situated in the centre of the Pannonian Basin whereas the Middle and Upper Rhyolite Tuffs are close to the surrounding mountains. Tuff horizons are also frequent in the Transylvanian Basin and the West Carpathians (Pécskay et al., 1995b; Bojar et al., 2012). The eruption centres associated with these pyroclastic rocks remain uncertain (Sza-
Sarmatian to recent alkaline volcanism, dominated by alkaline sodic volcanic rocks. The ages range from 11.5 to 0.1 Ma (Pécskay et al., 1995b, 2006). The oldest ages are again found in the western part of the Pannonian Basin and in the western marginal basins ( 11.5 to $10.5 \mathrm{Ma}$ in the Styrian Basin and 12 to $10.5 \mathrm{Ma}$ in the Danube Basin). The age of the alkaline volcanism in the Alpine-Carpathian-Pannonian area is generally younger than the calc-alkaline one and, in the regions with calc-alkaline and alkaline volcanism, it post-dates the former after an interruption. Two age peaks can be roughly put in evidence, at 12 to $8 \mathrm{Ma}$ and 4 to $0 \mathrm{Ma}$. As outlined before, part of the Badenian volcanism of the Styrian Basin is high-K calc-alkaline to shoshonitic, but they are discussed together with the calc-alkaline series because of their close relationship to each other in time and regional distribution. There is not such an obvious trend in age development as for the calc-alkaline volcanism. Regionally, the alkaline volcanism is more frequently represented in the northern and western parts of the Pannonian Basin. The exceptions are occurrences in the Banat, Apuseni Mountains and Calimani-Harghita Mountains, showing ages less than $2 \mathrm{Ma}$ (Pécskay et al., 1995b, 2006). The alkaline volcanism in the Alpine-Carpathian-Pannonian area is represented by nepheline basanites, nephelinites, trachyandesite, trachybasalts, nepheline tephrites and hawaaite (Dobosi et al., 1995; Harangi et al., 1995a; Pécskay et al., 1995b, 2006; Harangi and Lenkey, 2007) that occur as lava-flows, scattered necks, cinder- and tuff cones. Mantle-derived ultramafic xenoliths and phenocrysts of amphibole and pyroxenes are frequent in the tuffs and less common in lava flows of the alkaline volcanism (Kurat et al., 1991; Zanetti et al., 1995; Dobosi et al., 1998, 2003; Dobosi and Jenner, 1999; Demény et al., 2005). The most prominent occurrences are in the southeastern Styrian Basin, in adjacent Burgenland basement high, in Slovenia (Scharbert et al., 1981; Kurat et al., 1991; Balogh et al., 1994; Coltori et al., 2007; Kralj, 2011), in the Banat and South Harghita Mountains (Downes et al., 1995b), in the Little Hungarian Plain (Falus et al., 2007), Nógrád (Konečný et al., 1995a; Dobosi and Jenner, 1999; Demény et al., 2005) and in the Balaton-Bakony area, Hungary (Embey-lsztin et al., 2001; Dobosi et al., 2003; Nedli et al., 2009). 
Volcanological/geophysical investigations were done for Altenmarkt and Riegersburg (Fritz, 1996a), Burgfeld-Beistein (Pöschl, 1991) and the Grad volcanogenic field (Kralj, 2011), the Gleichenberg volcanic field (Winkler, 1913), Unterweissenbach and Gniebing (Murban, 1939), Kapfenstein (Winkler v. Hermaden, 1957), Limbach (Jugovics, 1916; Sauerzopf, 1986) and Tobaj (Jugovics, 1916). Summaries can be found in Sigmund (1899), Flügel and Heritsch (1968) and Fritz (1996b). Of broad interest are the mantle xenoliths and large phenocrysts for which several petrological and geochemical studies were carried out by Richter (1971), Kurat et al. (1980), EmbeyIsztin et al. (1990), Kurat et al. (1991), Downes and Vaselli (1995), Vaselli et al. (1995, 1996), Szabó et al. (1995), Dobosi et al. (1998), Demény et al. (2005) and Coltori et al. (2007).

The distribution of the Neogene volcanic rocks in the Styrian Basin and adjacent areas are given in Figures 1 and 2. Two arrays of volcanic occurrences are situated westward and eastward of the Auersbach basement high (numbers 1 to 17 in Fig. 3). The trachyte-trachyandesite volcano of Bad Gleichenberg, belonging also to these arrays, has an age of 13.2 to 15.4 (Balogh et al., 1994; Handler et al., 2006; Bojar et al., 2008) and was affected by a younger phreatomagmatic volcanism represented by a volcano-sedimentary sequence lying on this volcano. The third array (numbers 18 to 21 in Fig. 3) hosts a small effusive occurrence at Stein. The easternmost array in Burgenland is represented only by three tuff occurrences (23 to 25 in Fig. 3).

The amphibole and pyroxene phenocrysts associated with the investigated tuffs can be interpreted as fragments of disrupted mantle assemblages. The composition, large size, fragmentation and irregular edges to the hosting basalt indicate that many amphiboles could be derived from disaggregated dikes or cumulates crystallized from mafic magmas (Righter and Carmichael, 1993; Shaw and Eyzaguirre, 2000). Further crystallochemical studies confirm this genesis (Shaw and Eyzaguirre, 2000; Dobosi et al., 2003; Downes et al., 2004; Demeny et al., 2005). The phenocrysts were brought to the surface by later basaltic magmatism (Downes et al., 1995b; Huraiová et al., 1996; Dobosi et al., 2003; Demeny et al., 2005). Clinopyroxene/amphibole phenocrysts and ultramafic xenoliths occur frequently together and are also probably formed from mafic magmas at high pressures (Dobosi et al., 2003). For this study, it was possible to sample ultramafic xenoliths and phenocrysts from almost all volcanic tuff occurrences. Just for the locations Jennersdorf, Jobst and Grad, no adequate material was available. Commonly, amphibole crystals are more frequent than pyroxenes; at Neuhaus exclusively pyroxenes were found. In Table 3 , a compilation of the size and the relative frequency of ultramafic xenoliths and amphibole phenocrysts of the known tuff locations are given. A correlation was observed between relative frequency and the maximum size of ultramafic xenoliths and phenocrysts.
The most recent volcanic cycle of the Styrian Basin is mainly basaltic and shows effusive and explosive characteristics. The tuff occurrences are interpreted as phreatomagmatic eruptions with partially reworked debris flows and maar development (Pöschl, 1991; Fritz, 1996a, b; Kralj, 2011). Such maar-volcanoes, which consist largely of tephra layers, are extremely rich in country rocks (Fritz, 1996b). For example, the bulk rock at the Grad volcano consists of $35 \%$ non-volcanic detritus (Kralj, 2000). In some areas, bomb-sag structures can be found, indicating wet surface conditions (Pöschl, 1991; Fritz, 1996a, b). Geochronological data (this study and data from Table 1) on amphibole phenocrysts from the Styrian Basin tuffs show an age range between 7.51 and $2.73 \mathrm{Ma}$ indicating a time-span of the youngest alkaline effusive and explosive volcanism cycle around $6 \mathrm{Ma}$. Stratigraphically, the volcanism began according to the Central Paratethyan timescale (Rögl, 1998; Vasiliev et al., 2004) in latest Pannonian and ended in Romanian times.

\section{CONCLUSIONS}

The youngest volcanism in the Styrian Basin and adjoining areas started with phreatomagmatic events and ended with effusive alkaline volcanism, showing a similar time span as the volcanism of the Transdanubian Central Range (2.3 to 7.5 Ma), the Danube Basin (3.0 to $5.5 \mathrm{Ma}$ ) and the Nógrád/Novohrad area (1.1 to 7.2 Ma; Pécskay et al., 1995b, 


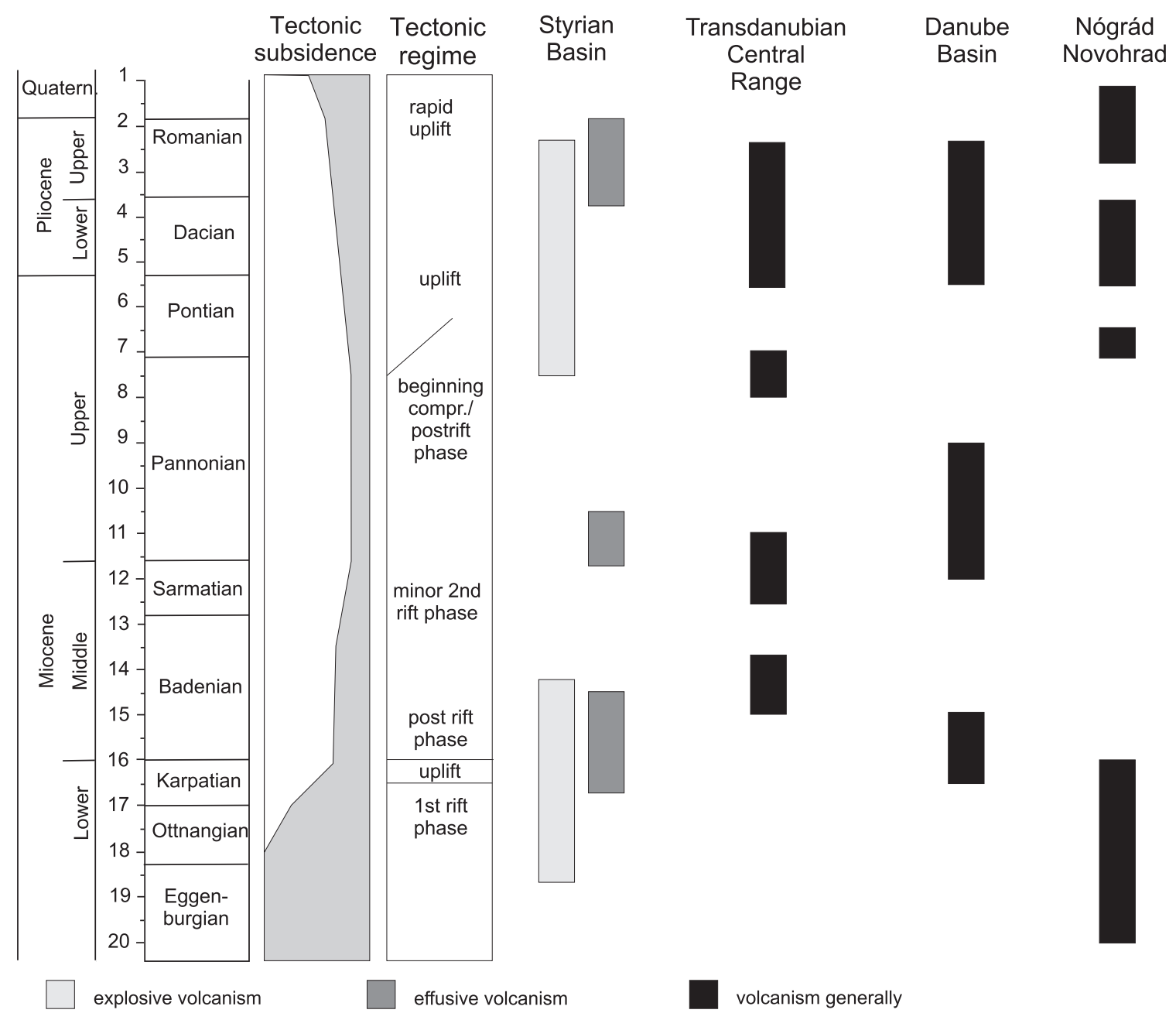

Fig. 5. Age distribution of volcanic rocks from the Styrian Basin and adjoining areas

Geochronological data are based on Tables 1 and 2; tectonic subsidence and regime are according to Sachsenhofer (1996); age distribution from the Transdanubian Range, the Danube Basin and the Nógrád/Novohrad area are according to Pécskay et al. (1995b, 2006)

2006). Combining previous data with the new ages presented in this study, gives roughly two peaks for the youngest alkaline volcanism in the Styrian Basin and adjoining areas: the first at 5 to $5.5 \mathrm{Ma}$ and the second at 2.5 to $3 \mathrm{Ma}$ (Fig. 6). The dated volcanic occurrences display NNW-SSE oriented arrays which are more or less parallel to the Auersbach high zone. These arrays are approximately perpendicular to the direction of compression (Fig. 5).

The evolution of the Styrian Basin can be divided into three phases according to subsidence analyses and quantitative modelling (Sachsenhofer, 1996; Sachsenhofer et al., 1997): an Early Miocene (Ottnangian to Karpatian) synrift and a Sarmatian extension phase, termination of subsidence during the Pannonian and, finally, rapid uplift during the Quaternary. The Badenian volcanic cycle of the Styrian Basin in the Karpatian, which coincides with extreme subsidence rates, continued until the end of the Lower Badenian (Sachsenhofer, 1996). The Late Miocene to Pliocene volcanic cycle of the Styrian Basin and adjacent areas started with the beginning of the compression and the eastward tilting of the basin $(\sim 7 \mathrm{Ma})$. This phase of volcanism ended with the onset of the rapid uplift at the beginning of the Quaternary ( 2 Ma).

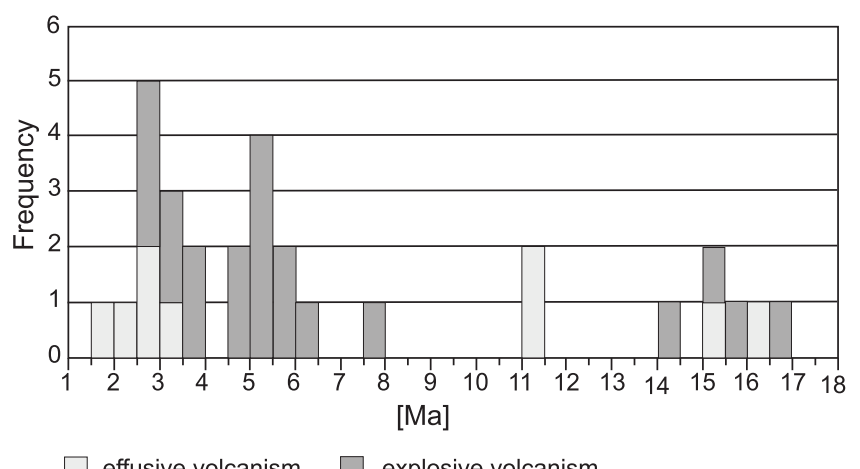

$\square$ effusive volcanism $\square$ explosive volcanism

Fig. 6. Histogram of geochronological data of volcanic rocks from the Styrian Basin and adjacent areas

Data are based on Tables 1 and 2; for the localities, from which more than one age is available, the arithmetic mean is displayed 
Acknowledgements. F. Neubauer (Salzburg) and N. Har (Cluj-Napoca) are thanked for a helpful review and constructive comments improving the manuscript. T.M. Peryt (Warszawa) is thanked for editorial comments and handling of the manuscript.

\section{REFERENCES}

Ali S., Ntaflos T. (2011) Alkali basalt from Burgenland, Austria: petrological constraints on the origin of the westernmost magmatism in the Carpathian-Pannonian Region. Lithos, 121: 176-188.

Balogh K., Ebner F., Ravasz C. (1994) K/Ar Alter tertiärer Vulkanite der südöstlichen Steiermark und des südlichen Burgenlandes. Geologische Bundesanstalt Wien, 2: 55-72.

Bergerat F. (1989) From pull-apart to the rifting process: the formation of the Pannonian Basin. Tectonophysics, 157: 271-280.

Bergerat F. (1995) The Moesian platform as a piece for the understanding of the geodynamical evolution of the Carpatho-Balkan Alpine system. In: Peri-Tethys Memoir 3: Stratigraphy and Evolution of Peri-Tethyan Platforms (ed. S.A.B. Crasquin-Soleau): 143-164. Memoirs du Museum d'Histoire Naturelle.

Bojar A.-V., Hałas S., Bojar H.-P., Szaran J. (2008) Isotopic evidence for the origin of an acid sulphate alteration, Styrian basin, Austria. Terra Nova, 20: 45-51.

Bojar A.-V., Barbu V., Bojar H.-P. (2012) Middle Miocene zeolite-bearing turbidites in the Abrămuț Basin (Pannonian Basin) NW Romania. Geological Quarterly, 56 (2): 261-268.

Coltori M., Bonadiman C., Faccini B., Ntaflos T., Siena F. (2007) Slab melt and intraplate metasomatism in Kapfenstein mantle xenoliths (Styrian Basin, Austria). Lithos, 94: 66-89.

Cox A., Dalrymple G.B. (1967) Statistical analysis of geomagnetic reversal data and the precision of potassium-argon dating. Journal of Geophysical Research, 72: 2603-2614.

Csontos L., Tari G., Bergerat F., Fodor L. (1991) Evolution of the stress fields in the Pannonian area during the Neogene. Tectonophysics, 199: 73-91.

Csontos L. (1995) Tertiary tectonic evolution of the Intra-Carpathian area: a review. Acta Vulcanologica, 7: 1-15.

Demény A., Vennemann T.W., Homonnay Z., Milton A., EmbeyIsztin A., Nagy G. (2005) Origin of amphibole megacrysts in the Pliocene-Pleistocene basalts of the Carpathian-Pannonian region. Geologica Carpathica, 56: 179-189.

Dobosi G., Jenner G.A. (1999) Petrological implications of trace element variation in clinopyroxene megacrysts from Nógrád volcanic province, north Hungary: a study by laser ablation microprobe-inductively coupled plasma-mass spectrometry. Lithos, 46: 731-749.

Dobosi G., Fodor R.V., Goldberg S.A. (1995) Late-Cenozoic alkali basalt magmatism in Northern Hungary and Slovakia: petrology, source compositions and relationship to tectonics. Acta Vulcanologica, 7: 199-207.

Dobosi G., Downes H., Mattey D., Embey-Isztin A. (1998) Oxygen isotope ratios of phenocrysts from alkali basalts of the Pannonian basin: evidence for an O-isotopically homogeneous upper mantle beneath a subduction-influenced area. Lithos, 42: 213-223.

Dobosi G., Downes H., Embey-Isztin A., Jenner G.A. (2003) Origin of megacrysts and pyroxenite xenoliths from the Pliocene alkali basalts of the Pannonian Basin (Hungary). Neues Jahrbuch Mineralogie Abhandlungen, 178: 217-237.

Downes H., Vaselli O. (1995) The lithospheric mantle beneath the Carpathian-Pannonian Region; a review of trace element and isotopic evidence from ultramafic xenoliths. Acta Vulcanologica, 7: $219-229$.

Downes H., Pantó G., Póka T., Mattey D.P., Greenwood P.B. (1995a) Calc-alkaline volcanic of the Inner Carpathian arc, Northern Hungary: new geochemical and oxygen isotopic results. Acta Vulcanologica, 7: 29-41.
Downes H., Seghedi I., Szakács A., Dobosi G., James D.E., Vaselli O., Rigby I.J., Ingram G.A., Rex D., Pécskay Z. (1995b) Petrology and geochemistry of late Tertiary/Quaternary mafic alkaline volcanism in Romania. Lithos, 35: 65-81.

Downes H., Beard A., Hinton R. (2004) Natural experimental charges: an ion-microprobe study of trace element distribution coefficients in glass-rich hornblendite and clinopyroxenite xenoliths. Lithos, 75: 1-17.

Durakiewicz T. (1995) Datowanie minerałów i skał w oparciu o rozpad promieniotwórczy potasu-40. II Ogólnopolska Sesja Naukowa, UMCS, Lublin: 44-52.

Ebner F. (1981) Vulkanische Tuffe im Miozän der Steiermark. Mitteilungen des Naturwissenschaftlichen Vereins für Steiermark, 111: $39-55$.

Ebner F., Gräf W. (1982) Bentonite und Glastuffe der Steiermark. Archiv für Lagerstättenforschung der Geologischen Bundesanstalt, 2: $31-45$

Ebner F., Sachsenhofer R.F. (1995) Paleogeography, subsidence and thermal history of the Neogene Styrian Basin (Pannonian basin system, Austria). Tectonophysics, 242: 133-150.

Ebner F., Dunkl I., Mali H., Sachsenhofer R.F. (2002) Stratigraphic evidence of pyroclastic layers in Miocene basins of the Eastern Alps (Austria). Geologica Carpathica, Spec. Issue, 53, CD-ROM.

Embey-Isztin A., Dobosi G. (1995) Mantle source characteristics for Miocene-Pliocene alkali basalts, Carpathian-Pannonian region: a review of trace elements and isotopic compositions. Acta Vulcanologica, 7: 155-166.

Embey-Isztin A., Scharbert H.G., Dietrich H., Pultidis H. (1990) Mafic granulites and clinopyroxenite xenoliths from the Transdanubian Volcanic Region (Hungary): implications for the deep structure of the Pannonian Basin. Mineralogical Magazine, 54: 463-483.

Embey-Isztin A., Dobosi G., Altherr R., Meyer H.P. (2001) Thermal evolution of the lithosphere beneath the western Pannonian Basin: evidence from deep-seated xenoliths. Tectonophysics, 331: 285-306.

Falus G., Szabó C., Kovács I., Zajacz Z., Halter W. (2007) Symplectite in spinel Iherzolite xenliths from the Little Hungarian Plain, Western Hungary: a key for understanding the complex history of the upper mantle of the Pannonian Basin. Lithos, 94: 230-244.

Flügel H., Heritsch H. (1968) Das Steirische Tertiär Becken Sammlung geologischer Führer, 47, Gebrüder Bornträger.

Flügel H.W., Neubauer F. (1984) Steiermark - Geologie der österreichischen Bundesländer in kurzgefassten Einzeldarstellungen. Geologische Bundesanstalt, Wien, 127.

Fodor L. (1995) From transpression to transtension; Oligocene-Miocene structural evolution of the Vienna Basin and the East Alpine-West Carpathian junction. Tectonophysics, 242: 151-182.

Fodor L., Csontos L., Bada G., Benkovics L. (2000) Tertiary tectonic evolution of the Pannonian basin and neighbouring orogens; a new synthesis of paleostress data. Geological Society Special Publications, 134: 295-334.

Friebe G. (1991) Neotektonik an der Mittelsteirischen Schwelle (Österreich): Die "Steirische Phase". Zentralblatt für Geologie und Paläontologie Teil I, 1: 41-54.

Fritz I. (1996a) Die Entwicklung der jungpleistozänen Vulkanoklastika im Raum Altenmarkt-Riegersburg und ihre Beziehung zu den umstehenden Sedimenten. Unpublished PhD thesis, Karl-Franzens University Graz, Austria. 
Fritz I. (1996b) Notes on the Plio-/Pleistocene volcanism of the Styrian Basin. Mitteilungen der Gesellschaft der Geologie- und Bergbaustudenten Österreichs, 41: 87-100.

Genser J., Neubauer F. (1989) Low angle faults at the eastern margin of the Tauern window (Eastern Alps). Mitteilungen der Österreichischen Geologischen Gesellschaft, 81: 233-243.

Hałas S. (2001) Elemental analysis by isotope dilution technique on the example of \% K determination in minerals to be dated by K/Ar method. Elektronika, 42 (8-9): 53-55.

Handler R., Ebner F., Neubauer F., Bojar A.-V., Hermann S. (2006) ${ }^{40} \mathrm{Ar} /{ }^{39} \mathrm{Ar}$ dating of Miocene tuffs from the Styrian part of the Pannonian Basin: an attempt to refine the basin stratigraphy. Geologica Carpathica, 57: 483-494.

Harangi S., Lenkey L. (2007) Genesis of the Neogene to Quaternary volcanism in the Carpathian-Pannonian region: Role of subduction, extension and mantle plume. GSA Special Publication, 418: 67-92.

Harangi S., Wilson M., Tonarini S. (1995a) Petrogenesis of Neogene potassic volcanic rocks in the Pannonian Basin. Acta Vulcanologica, 7: 125-134.

Harangi S., Vaselli O., Tonarini S., Szabó C., Harangi R., Coradossi N. (1995b) Petrogenesis of neogene extension related alkaline volcanic rocks of the Little Hungarian Plain Volcanic Field (West Hungary). Acta Vulcanologica, 7: 173-187.

Heritsch F. (1908) Über einige Einschlüsse und vulkanische Bomben von Kapfenstein. Centralblatt für Mineralogie, 10: 297-305.

Hippolyte J.C., Sandulescu M. (1996) Paleostress characterisation of the "Walachian phase" in its type area (South Eastern Carpathians, Romania). Tectonophysics, 263: 235-248.

Horváth F. (1993) Towards a mechanical model for the formation of the Pannonian Basin. Tectonophysics, 226: 333-357.

Horváth F. (1995) Phases of compression during evolution of the Pannonian Basin and its bearing on hydrocarbon exploration. Marine and Petroleum Geology, 12 (8): 837-844.

Horvath F., Bada G., Szafián P., Tari G., Ádám A., Cloething S. (2006) Formation and deformation of the Pannonian basin: constraints from observational data. Geological Society, Memoirs, 32: 191-206.

Huismans R.S., Bertotti G. (2002) The Transylvanian basin, transfer zone between coeval extending and contracting regions: Inferences on the relative importance of slab pull and rift push in arc-back arc systems. Tectonics, 21: 1-19.

Huismans R.S., Bertotti G., Ciulavu D., Sanders C.A., Cloetingh S.A.P.L., Dinu C. (1997) Structural evolution of the Transylvanian Basin (Romania): a sedimentary basin in the bend zone or the Carpathians. Tectonophysics, 272: 249-268.

Huismans R.S., Podladchikov Y.Y., Cloetingh S.A.P.L. (2002) The Pannonian basin: dynamic modelling of the transition from passive to active rifting. EGU Stephan Müller Special Publications, 3: 41-63.

Jugovics L. (1916) Die am Fusse der östlichen Endigung der Alpen und im Kleinen Ungarischen Alföld/Tiefland im Kommitat Vas auftauchenden Basalte und Basalttuffe. Jahresberichte der Königlichen Ungarischen Geologischen Reichsanstalt: 51-79.

Lippolt J., Baranyi I., Todt W. (1975) Das Kalium-Argon-Alter des Basaltes vom Lavant-Tal in Kärnten. Der Aufschluss, 26: 238-242

Kaličiak M.I., Žec B. (1995) Review of the Neogene volcanism of Eastern Slovakia. Acta Vulcanologica, 7: 87-95.

Kantor J., Harcova E., Rucky U. (1987) Izotopicky vyskum a radiometricke datovanie $z$ oblasti Vel'kej Bratislavy. Open file report Geofond, Bratislava.

Kollmann K. (1964) Jungtertiär im Steirischen Becken. Mitteilungen der Geologischen Gesellschaft Wien, 57 (2): 479-632

Kollmer H. (1980) Das Rb-Sr-Alter oststeirischer Vulkanite. Mitteilungen des naturwissenschaftlichen Vereines für Steiermark, 110: 23-26.

Konečný P., Konečný V., Lexa J., Huraiova M. (1995a) Mantle xenoliths in alkali basalts of Southern Slovakia. Acta Vulcanologica, 7: 241-247.

Konečný V., Lexa J., Hojstričová V. (1995b) The Central Slovakia Neogene volcanic field: a review. Acta Vulcanologica, 7: 63-78.
Kralj P. (2000) Upper Pliocene alkali basalt at Grad, northeastern Slovenia. Geologija, 43 (2): 213-218.

Kralj P. (2011) Eruptive and sedimentary evolution of the Pliocene Grad Volcanic Field, North-east Sleovenia. Journal of Volcanology and Geothermal Research, 201: 272-284.

Kröll A. (1988) Prätertiärer Untergrund des Steirischen Beckens und der Südburgenländischen Schwelle 1:200.000. Verlag der Geologischen Bundesanstalt, Wien.

Kröll A., Flügel H.W., Seiberl W., Weber F., Walach G., Zych D. (1988) Erläuterungen zu den Karten über den prätertiären Untergrund des Steirischen Beckens und der Südburgenländischen Schwelle. Geologische Bundesanstalt Wien.

Kurat G., Palme H., Spettel B., Baddenhausen H., Hofmeister H., Palme C., Wänke H. (1980) Geochemistry of ultramafic xenoliths from Kapfenstein, Austria: evidence for a variety of upper-mantle processes. Geochimica et Cosmochimica Acta, 44: 45-60.

Kurat G., Embey-Isztin A., Kracher A., Scharbert H.G. (1991) The Upper Mantle Beneath Kapfenstein and the Transdanubian Volcanic Region, E Austria and W Hungary: a comparison. Mineralogy and Petrology, 44: 21-38.

Lyashkevich Z.M. (1995) Neogene volcanic rocks of the Ukrainian Carpathians: abrief review. Acta Vulcanologica, 7: 79-85.

Mațenco L. (1997) Tectonic evolution of the Outer Romanian Carpathians; constraints from kinematic analyses and flexural modelling. Ph.D. thesis, Vrije Universiteit Amsterdam.

Moriya I., Okuno M., Nakamura T., Ono K., Szakács A., Seghedi I. (1996) Radiocarbon ages of charcoal fragments from the pumice flow deposit of the last eruption of Ciomadul volcano, Romania. Summaries of Researches Using AMS at Nagoya University, 6: 82-91

Murban K. (1939) Die vulkanischen Durchbrüche in der Umgebung von Feldbach. Mitteilungen der Abteilung Bergbau, Geologie und Paläontologie, Landesmuseum Joanneum, 3: 3-11.

Nédli Z., Princivalle F., Dobosi G., Embey-Isztin A. (2009) Crystal chemistry of clinopyroxenes from upper-mantle xenoliths series in the Balaton-Bakony volcanic ares (Carpathian-Pannonian region, Hungary. European Journal of Mineralogy, 21: 433-442.

Németh K., Martin U., Harangi S. (2001) Miocene phreatomagmatic volcanism at Tihany (Pannonian Basin, Hungary). Journal of Volcanology and Geothermal Research, 111: 111-135.

Neubauer F. (1988) Bau und Entwicklungsgeschichte des Rennfeld, Mugel- und des Gleinalmkristallins (Ostalpen). Abhandlungen der Geologischen Bundesanstalt, 42.

Neubauer F., Genser J. (1990) Architektur und Kinematik der östlichen Zentralalpen - eine Übersicht. Mitteilungen des Naturwissenschaftlichen Vereines für Steiermark, 120: 203-219.

Pécskay Z., Edelstein O., Seghedi I., Szakács A., Kovács M., Crihan M., Bernad A. (1995a) K/Ar datings of Neogene-Quarternary calc-alkaline volcanic rocks in Romania. Acta Vulcanologica, 7: 53-61.

Pécskay Z., Lexa J., Szakács A., Balogh K., Seghedi I., Konečný V., Kovác M., Márton E., Kaličiak M., Széky-Fux V., Póka T., Gyarmati P., Edelstein O., Roşu E., Žec B. (1995b) Space and time distribution of Neogene-Quaternary volcanism in the Carpatho-Panonnian region. Acta Vulcanologica, 7: 15-28.

Pécskay Z., Lexa J., Szakács A., Seghedi I., Balogh K., Konečný V., Zelenka T., Kovác M., Póka T., Fülöp A., Márton E., Panaiotu C., Cvetkovic V. (2006) Geochronology of Neogene magmatism in the Carpathian arc and intra-Carpathian area. Geologica Carpathica, 57: 511-530.

Peltz S., Vajdea E., Balogh K., Pécskay Z. (1987) Contributions to the chronological study of the volcanic processes in the Călimani and Harghita mountains (East Carpathians, Romania). Dari de Seamă ale Institutului de Geologie şi Geofizica, 72-73: 323-338.

Peresson H., Decker K. (1996) From extension to compression: Late Miocene inversion in the Alpine-Carpathian-Pannonian transition area. Mitteilungen der Gesellschaft der Geologie- und Bergbaustudenten Österreichs, 41: 75-86.

Peresson H., Decker K. (1997a) Far field effects of late Miocene subduction in the Eastern Carpathians; E-W compression and 
inversion structures in the Alpine Carpathian Pannonian region. Tectonics, 16: 38-56.

Peresson H., Decker K. (1997b) The Tertiary dynamics of the northern Eastern Alps (Austria): changing paleostress in a collisional plate boundary. Tectonophysics, 272: 125-157.

Pöschl I. (1991) A model for the depositional Evolution of the volcanoclastic succession of a Pliocene Maar Volcano in the Styrian Basin (Austria). Jahrbuch der Geologischen Bundesanstalt, 134 (4): 809-743.

Ratschbacher L., Frisch W., Neubauer F., Schmid S.M., Neugebauer J. (1989) Extension in compressional orogenic belts: the Eastern Alps. Geology, 17: 407-407.

Ratschbacher L., Frisch W., Linzer H.-G., Merle O. (1991) Lateral extrusion in the Eastern Alps, 2. Structural analysis. Tectonics, 10: $257-271$

Ratschbacher L., Linzer H.G., Moser F., Strusievicz R.O., Bedelean H., Har N., Mogos P.A. (1993) Cretaceous to Miocene thrusting and wrenching along the central South Carpathians due to a corner effect during collision and orocline formation. Tectonics, 12: 855-87.

Richter W. (1971) Ariegite, Spinell-Peridotite und Phlogopit-Klinopyroxenite aus dem Tuff von Tobaj im südlichen Burgenland. Tschermaks Mineralogische und Petrographische Mitteilungen III, 16 (4): 227-132.

Righter K., Carmichael I.S.E. (1993) Mega-xenocrysts in alkali olivine basalts: Fragments of disrupted mantle assemblages. American Mineralogist, 78: 1230-124.

Rögl F. (1998) Paleogeographic considerations for Mediterranean and Paratethys Seaway (Oligocene to Miocene). Annalen des Naturhistorischen Museums Wien, 99A: 279-310.

Royden L.H. (1993) The tectonic expression slab pull at continental convergent boundaries. Tectonics, 12: 303-325.

Royden L.H., Horváth F., Rumpler J. (1983) Evolution of the Pannonian Basin System 1. Tectonics. Tectonics, 2: 63-90.

Sachsenhofer R.F. (1996) The Neogene Styrian Basin: an overview. Mitteilungen der Gesellschaft der Geologie- und Bergbaustudenten Österreichs, 41: 19-32.

Sachsenhofer R.F., Lankreijer A., Cloetingh S., Ebner F. (1997) Subsidence analysis and quantitative basin modelling in the Styrian Basin (Pannonian Basin System, Austria). Tectonophysics, 272: 175-196.

Sanders C.A.E. (1998) Tectonics and erosion, competitive forces in a compressive orogen. A fission track study of the Romanian Carpathians. Ph.D. thesis, Vrije Universiteit Amsterdam.

Sauerzopf F. (1986) Zur Kenntnis der Verbreitung von der Tuffe Limbach/Kukmirn im Bezirk Güssing/Burgenland. Berichte des Biologischen Forschungsinstituts Burgenland, $\mathbf{5 7}$

Schadler J. (1913) XVI. Zur Kenntnis der Einschlüsse in den südsteirischen Basalttuffen und ihrer Mineralien. Tschermaks Mineralogische und Petrographische Mitteilungen, 22: 485-511.

Scharbert H.G., Poultidis C., Höller H., Kolmer H., Wirsching U. (1981) Vulkanite im Raume Burgenland - Oststeiermark. Fortschritte der Mineralogie Beiheft, 2: 69-88.

Sclater J.G., Royden L., Horvath F., Burchfiel B.C., Semken S., Stegena L. (1980) The formation of the intra-Carpathian basins as determined from subsidence data. Earth and Planetary Science Letters, 51: 139-162.

Seghedi I., Szakács A., Mason P.R.D. (1995) Petrogenesis and magmatic evolution in the East Carpathians Neogene volcanic arc (Romania). Acta Vulcanologica, 7: 135-143.
Seghedi I., Downes H., Vaseli O., Szakács A., Balogh K., Pécskay Z. (2004) Post-collisional Tertiary-Quaternary mafic alkali magmatism in the Carpatho-Pannonian region: a review. Tectonophysics, 393: 43-62.

Seghedi I., Mațenco L., Downes H., Mason P.R.D., Szakács A., Pécskay Z. (2011) Tectonic significance of changes in postsubduction Pliocene-Quaternary magmatism in the south east part of the Carpathian-Pannonian region. Tectonophysics, 502: 146-157.

Shaw C.S.J., Eyzaguirre J. (2000) Origin of megacrysts in the mafic alkaline lavas of the West Eifel volcanic field, Germany. Lithos, 50: 75-95.

Sigmund A. (1899) XIV. Die Basalte der Steiermark. Tschermaks Mineralogische und Petrographische Mitteilungen, 18: 377-407.

Slapansky P., Belocky R., Fröschl H., Hradecky P., Spindler P. (1999) Petrographie, Geochemie und geotektonische Einstufung des miozänen Vulkanismus im Steirischen Becken. Abhandlungen der Geologischen Bundesanstalt, 56 (1): 419-434.

Steininger F.F., Bagdasarjan G.P. (1977) Neue radiometrische Alter mittelmiozäner Vulkanite der Steiermark (Österreich), ihre biostratigraphische Korrelation und ihre mögliche Stellung innerhalb der paläomagnetischen Zeitskala. Verhandlungen der Geologischen Bundesanstalt, 2: 85-99.

Szabó C., Harangi S., Csontos L. (1992) Review of the Neogene and Quaternary volcanism of the Carpathian-Pannonian region. Tectonophysics, 208: 1-3.

Szabó C., Harangi S., Vaselli O., Downes H. (1995) Temperature and oxygen fugacity in peridotite xenoliths from the Carpathian-Pannonian Region. Acta Vulcanologica, 7: 231-239.

Szakács A., Seghedi I., Pécskay Z. (1993) Pecularities of South Harghita Mts. as the terminal segment of the Carpathian Neogene to Quaternary volcanic chain. Revue Roumanie. Geologie, Geophysique et Geographie, 37: 21-37.

Tari G., Horváth F., Rumpler J. (1992) Styles of extension in the Pannonian Basin. Tectonophysics, 208: 203-219.

Vaselli O., Downes H., Thirwall M., Dobosi G., Coradossi N., Seghedi I., Szakács A., Vannucci R. (1995) Ultramafic xenoliths in Plio-Pleistocene Alkali basalts from the Eastern Transylvanian basin: depleted mantle enriched by vein metasomatism. Journal of Petrology, 1: 23-53.

Vaselli O., Downes H., Thirlwall M.F., Vanucci R., Coradossi N. (1996) Spinel-peridotite xenoliths from Kapfenstein (Graz Basin, Eastern Austria): a geochemical and petrological study. Mineralogy and Petrology, 57 (1-2): 23-50.

Vasiliev I., Krijgsman W., Langereis C.G., Panaiotu C.E., Matenco L., Bertotti G. (2004) Towards an astrochronological framework for the eastern Paratethys Mio-Pliocene sedimentary sequences of the Focşani basin (Romania). Earth and Planetary Science Letters, 227: 231-247.

Winkler A. (1913) Das Eruptivgebiet von Gleichenberg in Oststeiermark. Jahrbuch der kaiserlich-königlichen Geologischen Reichsanstalt, 63 (3): 403-502.

Winkler V., Hermaden A. (1957) Geologisches Kräftespiel und Landformung. Springer, Vienna.

Zanetti A., Vannucci R., Oberti R., Dobosi G. (1995) Trace element composition and crystal chemistry of mantle amphiboles from the Carpatho-Pannonian Region. Acta Vulcanologica, 7: 265-276. 